\title{
TWENTY-THIRD ANNUAL LIST OF PAPERS
}

\section{READ BEFORE THE AMERICAN MATHEMATICAL SOCIETY AND SUBSEQUENTLY PUBLISHED, INCLUDING REFERENCES TO THE PLACES OF THEIR PUBLICATION.}

Bauer, G. N., and Slobin, H. L. Some Transcendental Curves and Numbers. Read (Chicago) March 21, 1913. Rendiconti del Circolo Matematico di Palermo, vol. 36, No. 3, pp. 327-332; Nov.-Dec., 1913.

Beetre, R. D. A Formula in the Theory of Surfaces. Read Feb. 28, 1914. Annals of Mathematics, vol. 15, No. 4, pp. 179-183; June, 1914.

Bennetr, E. R. Simply Transitive Primitive Groups whose Maximal Subgroup Contains a Transitive Constituent of Order $p^{2}$, or $p q$, or a Transitive Constituent of Degree 5. Read Sept. 12, 1911. American Journal of Mathematics, vol. 36, No. 2, pp. 134-136; April, 1914.

Birкнoff, G. D. Quelques Théorèmes sur le Mouvement des Systèmes Dynamiques. Read Sept. 14, 1909. Bulletin de la Société Mathématique de France, vol. 40, No. 4, pp. 305-323; 1912.

- A Theorem on Matrices of Analytic Functions. Read Sept. 13, 1911. Mathematische Annalen, vol. 74, No. 1, pp. 122-133; June, 1913.

Note on the Gamma Function. Read April 26, $1913 . \quad$ Bulletin of the American Mathematical Society, vol. 20, No. 1, pp. 1-10; Oct., 1913.

On a Simple Type of Irregular Singular Point. Read Sept. 13, 1911. Transactions of the American Mathematical Society, vol. 14, No. 4, pp. 462-476; Oct., 1913.

The Generalized Riemann Problem for Linear Differential Equations, and the Allied Problems for Linear Difference and $q$-Difference Equations. Read April 26, 1913. Proceedings of the American Academy of Arts and Sciences, vol. 49, No. 9, pp. 521-568; Oct., 1913.

Démonstration du dernier Théorème de Géométrie de Poincaré. Read Oct. 26, 1912. Bulletin de la Société Mathématique de France, vol. 42 , No. 1, pp. 1-12; 1914.

Buiss, G. A., and WiLey, F. B. A Method of Subdividing the Area Enclosed by a Plane Curve, with an Application to Cauchy's Theorem. Read (Chicago) March 22, 1913. Bulletin of the Scientific Laboratories of Denison University, vol. 17, No. 11, pp. 374 ff; May, 1914.

Bôcher, M. Applications and Generalizations of the Conception of Adjoint Systems. Read April 26, 1913. Transactions of the American Mathematical Society, vol. 14, No. 4, pp. 403-420; Oct., 1913.

The Infinite Regions of Various Geometries. Read Sept. 8, 1913. Bulletin of the American Mathematical Society, vol. 20, No. 4, pp. 185200 ; Jan., 1914.

- On Gibbs's Phenomenon. Read (Chicago) March 22, 1913. Journal für die Reine und Angewandte Mathematik, vol. 144, No. 1, pp. 41-47; Jan., 1914.

BolzA, O. Über den "Anormalen Fall" beim Lagrangeschen und Mayerschen Problem mit gemischten Bedingungen und variablen Endpunkten. Read Sept.8, 1913. Mathematische Annalen, vol. 74, No. 3, pp. 430-446; Oct., 1913. 
Bussey, W. H. The Tactical Problem of Steiner. Read Sept. 8, 1913. American Mathematical Monthly, vol. 21, No. 1, pp. 3-12; Jan., 1914.

CAMP, B. H. A Method of Extending to Multiple Integrals Properties of Simple Integrals. Read Feb. 22, 1913. Mathematische Annalen, vol. 75, No. 2, pp. 274-289; April, 1914.

Carmichael, R. D. On Transcendentally Transcendental Functions. Read (Chicago) April 5, 1912. Transactions of the American Mathematical Society, vol. 14, No. 3, pp. 311-319; July, 1913.

On the Impossibility of Certain Diophantine Equations and Systems of Equations. Read (Chicago) March 21, 1913. American Mathematical Monthly, vol. 20, No. 7, pp. 213-221; Sept., 1913.

On the Numerical Factors of the Arithmetic Forms $\alpha^{n} \pm \beta^{n}$. Read Dec. 31, 1912. Annals of Mathematics, vol. 15, Nos. 1-2, pp. 30-70; Sept.-Dec., 1913.

On Certain Diophantine Equations having Multiple Parameter Solutions. Read (Chicago) March 21, 1913. American Mathematical Monthly, vol. 20, No. 10, pp. 304-307; Dec., 1913.

On Non-Homogeneous Equations with an Infinite Number of Variables. Read Dec. 31, 1912. American Journal of Mathematics, vol. 36, No. 1, pp. 13-20; Jan., 1914.

Some Theorems on the Convergence of Series. Read Sept. 8, 1913. Bulletin of the American Mathematical Society, vol. 20, No. 5, pp. 225233; Feb., 1914.

Chittenden, E. W. Relatively Uniform Convergence of Sequences of Functions. Read (Chicago) March 22, 1913. Transactions of the American Mathematical Society, vol. 15, No. 2, pp. 197-201; April, 1914.

Clements, G. R. Implicit Functions Defined by Equations with Vanishing Jacobian. Read April 28, 1911, and Oct. 26, 1912. Transactions of the American Mathematical Society, vol. 14, No. 3, pp. 325-342; July, 1913.

Singular Point Transformations in Two Complex Variables. Read April 28, 1911. Annals of Mathematics, vol. 15, No. 1, pp. 1-19; Sept., 1913.

Cosle, A. B. Restricted Systems of Equations. Read Dec. 31, 1913. American Journal of Mathematics, vol. 36, No. 2, pp. 1.67-186; April, 1914.

Coolidae, J. L. .Congruences and Complexes of Circles. Read Dec. 30, 1913. Transactions of the American Mathematical Society, vol. 15, No. 1, pp. 107-134; Jan., 1914.

Dickson, L. E. Proof of the Finiteness of Modular Covariants. Read (Chicago) March 22, 1913. Transactions of the American Mathematical Society, vol. 14, No. 3, pp. 299-310; July, 1913.

On the Rank of a Symmetrical Matrix. Read (Chicago) March 22, 1913. Annals of Mathematics, vol. 15, No. 1, pp. 27-28; Sept., 1913.

Finiteness of the Odd Perfect and Primitive Abundant Numbers with $n$ Distinct Prime Factors. Read Dec. 31, 1912. American Journal of Mathematics, vol. 35, No. 4, pp. 413-422; Oct., 1913.

Linear Associative Algebras and Abelian Equations. Read (Chicago) April 4, 1906, and Dec. 27, 1913. Transactions of the American Mathematical Society, vol. 15, No. 1, pp. 31-46; Jan., 1914. 
On Invariants and the Theory of Numbers. Read (Chicago) March 22, 1913, and Sept. 10-12, 1913. The Madison Colloquium Lectures, pp. 1-110; New York, 1914.

Dodd, E. L. The Error-Risk of Certain Functions of the Measurements. Read (Southwestern Section) Nov. 30, 1912. Monatshefte für Mathematik und Physik, vol. 24, Nos. 3-4, pp. 268-276; July, 1913.

A Justification of Empirical Probability based upon an Undetermined a priori Probability. Read (Chicago) March 21, 1913. Giornale di Matematiche, vol. 51, No. 5, pp. 257-263; Sept.-Oct., 1913.

The Error Risk of the Median Compared with that of the Arithmetic Mean. Read April 26, 1913. Bulletin of the University of Texas, Scientific Series, No. 27; March 15, 1914.

Dresden, A. On the Second Variation, Jacobi's Equation and Jacobi's Theorem for the Integral $\int F\left(x, y, x^{\prime}, y^{\prime}\right) d t$. Read (Chicago) Dec. 29, 1911. Annals of Mathematics, vol. 15, No. 2, pp. 78-83; Dec., 1913.

EeLLs, W. C. Number Systems of the North American Indians. Read (San Francisco) Oct. 25, 1913. American Mathematical Monthly, vol. 20, Nos. 9-10, pp. 263-272 and 293-299; Nov.-Dec., 1913: also in briefer form under the title: On Formation and Use of Numerals in Indian Languages of North America, Bibliotheca Mathematica, ser. 3, vol. 13, No. 3, pp. 218-222; July, 1913.

Eirssand, J. A. On the Algebraic Curves of a Tetrahedral Complex and the Surfaces Conjugate to it. Read Jan. 1, 1913. Rendiconti del Circolo Matematico di Palermo, vol. 36, No. 2, pp. 233-275; Sept.-Oct., 1913.

Eisenhart, L. P. Certain Continuous Deformations of Surfaces Applicable to Quadrics. Read Jan. 1, 1913. Transactions of the American Mathematical Society, vol. 14, No. 3, pp. 365-402; July, 1913.

- Transformations of Surfaces of Guichard and Surfaces Applicable to Quadrics. Read April 26, 1913. Annali di Matematica, ser. 3, vol. 22, Nos. 3-4, pp. 191-247; May, 1914.

Emch, A. On Closed Continuous Curves. Read (Southwestern Section) Nov. 30, 1912. Bulletin of the American Mathematical Society, vol. 20, No. 1, pp. 27-29; Oct., 1913.

- Geometric Properties of the Jacobians of a Certain System of Functions. Read (Chicago) Dec. 26, 1913. Annals of Mathematics, vol. 15, No. 3, pp. 136-144; March, 1914.

Two Convergency Proofs. Read Dec. 30, 1913. Bulletin of the American Mathematical Society, vol. 20, No. 7, pp. 358-364; April, 1914.

Evans, G. C. The Cauchy Problem for Integro-Differential Equations. Read Sept. 8, 1913. Transactions of the American Mathematical Society, vol. 15, No. 2, pp. 215-226; April, 1914.

Field, P. On Constrained Motion. Read Jan. 1, 1913. Zeitschrift für Mathematik und Physik, vol. 62, No. 3, pp. 309-319; Jan., 1914.

- On Constrained Motion. Read (Chicago) Dec. 27, 1913. American Journal of Mathematics, vol. 36, No. 1, pp. 21-30; Jan., 1914.

Fine, H. B. An Unpublished Theorem of Kronecker respecting Numerical Equations. Read Dec. 30, 1913. Bulletin of the American Mathematical Society, vol. 20, No. 7, pp. 339-358; April, 1914. 
Fischer, C. A. A Generalization of Volterra's Derivative of a Function of a Curve. Read Feb. 22, 1913. American Journal of Mathematics, vol. 35, No. 4, pp. 369-394; Oct., 1913.

Fite, W. B. Some Theorems concerning Groups whose Orders are Powers of a Prime. Read Jan. 2, 1913. Transactions of the American Mathematical Society, vol. 15, No. 1, pp. 47-50; Jan., 1914.

Fréchet, M. Sur les Classes V Normales. Read April 26, 1913. Transactions of the American Mathematical Society, vol. 14, No. 3, pp. 320324; July, 1913.

Sur la Notion de Différentielle d'une Fonction de Ligne. Read Sept. 9, 1913. Transactions of the American Mathematical Society, vol. 15, No. 2, pp. 135-161; April, 1914.

Frizeld, A. B. A Non-Enumerable Well-Ordered Set. Read (Chicago) Dec. 27, 1913. Bulletin of the American Mathematical Society, vol. 20, No. 8, pp. 404-405; May, 1914.

Glens, O. E. The Symbolical Theory of Finite Expansions. Read April 28, 1911, and (Chicago) March 22, 1913. Transactions of the American Mathematical Society, vol. 15, No. 1, pp. 72-86; Jan., 1914.

A Translation Principle connecting the Invariant Theory of Line Congruences with that of Plane $n$-Lines. Read Sept. 9, 1913. Bulletin of the American Mathematical Society, vol. 20, No. 5, pp. 233-238; Feb., 1914.

Graves, G. H. Complete Linear Systems of Algebraic Curves of Least Order of Genera Three and Four. Read Oct. 25, 1913. Author's Dissertation, 25 pp.; Lancaster, 1914.

Gronwall, T. H. Ueber die Laplacesche Reihe. Read Sept. 11, 1912. Mathematische Annalen, vol. 74, No. 2, pp. 213-270; Aug., 1913.

On the Summability of Fourier's Series. Read Feb. 22, 1913. Bulletin of the American Mathematical Society, vol. 20, No. 3, pp. 139146; Dec., 1913.

On the Degree of Convergence of Laplace's Series. Read Feb. 22, 1913. Transactions of the American Mathematical Society, vol. 15, No. 1, pp. 1-30; Jan., 1914.

- On Lebesgue's Constants in the Theory of Fourier's Series. Read Feb. 22, 1913. Annals of Mathematics, vol. 15, No. 3, pp. 125-128; March, 1914.

Hedrick, E. R. A Direct Definition of Logarithmic Derivative. Read (Southwestern Section) Nov. 30, 1912. American Mathematical Monthly, vol. 20, No. 6, pp. 185-187; June, 1913.

HedRick, E. R., and Ingold, L. A Set of Axioms for Line Geometry. Read (Southwestern Section) Dec. 2, 1911. Transactions of the American Mathematical Society, vol. 15, No. 2, pp. 205-214; April, 1914.

Hennes, C. B. Transformations and Invariants connected with Linear Homogeneous Difference Equations and Other Functional Equations. Read Jan. 1, 1913. American Journal of Mathematics, vol. 35, No. 4, pp. 431-452; Oct., 1913.

Hurwitz, W. A. Postulate Sets for Abelian Groups and Fields. Read April 26, 1913. Annals of Mathematics, vol. 15, No. 2, pp. 93-100; Dec., 1913. 
- Note on the Fredholm Determinant. Read Dec. 30, 1913. Bulletin of the American Mathematical Society, vol. 20, No. 8, pp. 406-408; May, 1914.

INGoLd, L. See Hedrick, E. R.

JACKson, D. On the Approximate Representation of an Indefinite Integral and the Degree of Convergence of Related Fourier's Series. Read Sept. 11, 1912, and Oct. 26, 1912. Transactions of the American Mathematical Society, vol. 14, No. 3, pp. 343-364; July, 1913.

On the Accuracy of Trigonometric Interpolation. Read Feb. 22, 1913. Transactions of the American Mathematical Society, vol. 14, No. 4, pp. 453-461; Oct., 1913.

KARPINSKI, I. C. The Whetstone of Witte (1557). Read (Chicago) March 21, 1913. Bibliotheca Mathematica, ser. 3, vol. 13, No. 3, pp. 223-228; July, 1913.

John Caswell. Read (Chicago) March 21, 1913. Bibliotheca Mathematica, ser. 3, vol. 13, No. 3, pp. 248-249; July, 1913.

- The Algebra of Abu Kamil. Read Sept. 12, 1911. American Mathematical Monthly, vol. 21, No. 2, pp. 37-48; Feb., 1914.

Kasner, E. The Ratio of the Arc to the Chord of an Analytic Curve Need Not Approach Unity. Read Sept. 9, 1913. Bulletin of the American Mathematical Society, vol. 20, No. 10, pp. 524-531; July, 1914.

Kelloga, O. D. Nomograms with Points in Alignment. Read (Chicago) March 22, 1913. Zeitschrift für Mathematik und Physik, vol. 63, Nos. 1-2, pp. 159-173; May, 1914.

Kells, L. M. Complete Characterization of Dynamical Trajectories in n-Space. Read Dec. 31, 1913. Author's Dissertation, 34 pp.; Lancaster, 1913.

LIPKA, J. Geometric Characterization of Isogonal Trajectories on a Surface. Read Jan. 1, 1913. Annals of Mathematics, vol. 15, No. 2, pp. 71-77; Dec., 1913.

Love, C. E. On the Irregular Integrals of Linear Differential Equations. Read (Chicago) Dec. 27, 1913. Annals of Mathematics, vol. 15, No. 3, pp. 145-156; March, 1914.

- On the Asymptotic Solutions of Linear Differential Equations. Read Jan. 2, 1913, and (Chicago) March 21, 1913. American Journal of Mathematics, vol. 36, No. 2, pp. 151-166; April, 1914.

McDonnell, J. On Quadratic Residues. Read (Chicago) March 22, 1913. Transactions of the American Mathematical Society, vol. 14, No. 4, pp. 477-480; Oct., 1913.

Manning, W. A. The Primitive Groups of Class Twelve. Read (San Francisco) Oct. 28, 1911. American Journal of Mathematics, vol. 35, No. 3, pp. 229-260; July, 1913.

- On the Class of Doubly Transitive Groups. Read (San Francisco) Oct. 25, 1913. Bulletin of the American Mathematical Society, vol. 20, No. 9, pp. 468-476; June, 1914.

Mrles, E. J. Some Properties of Space Curves Minimizing a Definite Integral with Discontinuous Integrand. Read Feb. 25, 1911. Bulletin of the American Mathematical Society, vol. 20, No. 1, pp. 11-19; Oct., 1913. 
Miller, G. A. On the Representation Groups of Given Abstract Groups. Read (Chicago) March 21, 1913. Transactions of the American Mathematical Society, vol. 14, No. 4, pp. 444-452; Oct., 1913.

A Non-Abelian Group whose Group of Isomorphisms is Abelian. Read (Chicago) Dec. 26, 1913. Messenger of Mathematics, vol. 43, No. 8, pp. 124-125; Dec., 1913.

A Group of Order $p^{m}$ whose Group of Isomorphisms is of Order $p^{\alpha}$. Read (Chicago) Dec. 26, 1913. Messenger of Mathematics, vol. 43, No. 8, pp. 126-128; Dec., 1913.

Some Properties of the Group of Isomorphisms of an Abelian Group. Read (San Francisco) Oct. 25, 1913. Bulletin of the American Mathematical Society, vol. 20, No. 7, pp. 364-368; April, 1914.

Mitchell, H. H. On Some Systems of Collineation Groups. Read April 26,1913. Bulletin of the American Mathematical Society, vol. 20, No. 3, pp. 134-138; Dec., 1913.

- Determination of All Primitive Collineation Groups in More than Four Variables which Contain Homologies. Read Sept. 10, 1912. American Journal of Mathematics, vol. 36, No. 1, pp. 1-12; Jan., 1914.

Moore, C. N. On the Summability of the Double Fourier's Series of Discontinuous Functions. Read Dec. 27, 1911. Mathematische Annalen, vol. 74, No. 4, pp. 555-572; Dec., 1913.

Morgan, F. M. See Sharpe, F. R.

Mourton, F. R. The Deviations of Falling Bodies. Read (Chicago) Dec. 26, 1913. Annals of Mathematics, vol. 15, No. 4, pp. 184-194; June, 1914.

Nyberg, J. A. Projective Differential Geometry of Rational Cubic Curves. Read April 28, 1911. American Journal of Mathematics, vol. 35, No. 4, pp. 453-464; Oct., 1913.

Osgood, W. F. Topics in the Theory of Functions of Several Complex Variables. Read Sept. 8 and Sept. 10-12, 1913. The Madison Colloquium Lectures, pp. 1-230; New York, 1914.

Pitcher, A. D. The Interrelations of Eight Fundamental Properties of Classes of Functions. Read (Chicago) April 10, 1909. Kansas University Science Bulletin, vol. 7, No. 1, pp. 1-68; June, 1913.

Reaves, S. W. On the Projective Differential Geometry of Plane Anharmonic Curves. Read (Southwestern Section) Nov. 30, 1912. Annals of Mathematics, vol. 15, No. 1, pp. 20-26; Sept., 1913.

Roever, W. H. The Design and Theory of a Mechanism for Illustrating Certain Systems of Lines of Force and Stream Lines. Read April 28, 1906, (Chicago) April 5, 1912, and (Southwestern Section) Nov. 30, 1912. Zeitschrift für Mathematik und Physik, vol. 62, No. 4, pp. 376384; March, 1914.

Optical Interpretations in Higher Geodesy. Read (Chicago) April 5, 1912. American Mathematical Monthly, vol. 21, No. 3, pp. 69-77; March, 1914.

Rоoт, R. E. Limits in Terms of Order, with Example of Limiting Element Not Approachable by a Sequence. Read (Chicago) March 21, 1913. Transactions of the American Mathematical Society, vol. 15, No. 1, pp. 51-71; Jan., 1914. 
Iterated Limits in General Analysis. Read (Chicago) Dec. 29, 1911. American Journal of Mathematics, vol. 36, Nos. 1-2, pp. 79-133; Jan.April, 1914.

Rowe, J. E. On Fermat's Theorem and Related Theorems. Read Sept. 8, 1913. Johns Hopkins University Circular, pp. 35-40; July, 1913.

The Relation between the Pencil of Tangents to a Rational Plane Curve from a Point and their Parameters. Read April 26, 1913. Messenger of Mathematics, vol. 43, No. 8, pp. 114-120; Dec., 1913.

RunNing, T. R. A Graphical Solution of the Differential Equation of the First Order. Read Sept. 9, 1913. American Mathematical Monthly, vol. 20, No. 9, pp. 279-281; Nov., 1913.

Sanderson, M. L. Formal Modular Invariants with Application to Binary Modular Covariants. Read (Chicago) March 21, 1913. Transactions of the American Mathematical Society, vol. 14, No. 4, pp. 489-500; Oct., 1913.

Schweitzer, A. R. Some Critical Remarks on Analytical Realism. Read Feb. 28, 1914. Journal of Philosophy, Psychology and Scientific Methods, vol. 11, No. 7, pp. 169-183; March 26, 1914.

Les Idées directrices de la Logique génétique des Mathématiques. Read April 28, 1911, and (Chicago) March 22, 1913. Revue de Métaphysique et de Morale, vol. 22, No. 2, pp. 174-196; March, 1914.

Sharpe, F. R., and Morgan, F. M. Quartic Surfaces Invariant under Periodic Transformations. Read Sept. 10, 1912, and Dec. 31, 1912. Annals of Mathematics, vol. 15, No. 2, pp. 84-92; Dec., 1913.

Sнaw, J. B. On Differential Invariants. Read (Chicago) Dec. 29, 1911. American Journal of Mathematics, vol. 35, No. 4, pp. 395-406; Oct., 1913.

Sheffer, H. M. A Set of Five Independent Postulates for Boolean Algebras, with Application to Logical Constants. Read Dec. 31, 1912. Transactions of the American Mathematical Society, vol. 14, No. 4, pp. 481-488; Oct., 1913.

Slobin, H. L. See Bauer, G. N.

Suluivan, C. T. Properties of Surfaces whose Asymptotic Curves Belong to Linear Complexes. Read April 26, 1913. Transactions of the American Mathematical Society, vol. 15, No. 2, pp. 167-196; April, 1914.

TaBer, H. On the Scalar Functions of Hypercomplex Numbers. Second Paper. Read Oct. 29, 1904. Proceedings of the American Academy of Arts and Sciences, vol. 48, No. 17, pp. 627-667; March, 1913.

Tracey, J. I. Covariant Curves of the Plane Rational Quintic. Read Dec. 31, 1913. American Journal of Mathematics, vol. 36, No. 1, pp. 31-46; Jan., 1914.

VANDIVER, H. S. Note on Fermat's Last Theorem. Read Feb. 28, 1914. Transactions of the American Mathematical Society, vol. 15, No. 2, pp. 202-204; April, 1914.

Webster, A. G. The Wave Potential of a Circular Line of Sources. Read Sept. 13, 1911. Proceedings of the American Academy of Arts and Sciences, vol. 47, No. 10, pp. 315-318; Dec., 1911.

Wedperburn, J. H. M. A Type of Primitive Algebra. Read Dec. 31, 1913. Transactions of the American Mathematical Society, vol. 15, No. 2, pp. 162-166; April, 1914. 
Westlund, J. On the Factorization of Rational Primes in Cubic Cyclotomic Number Fields. Read Jan. 1, 1913. Jahresbericht der Deutschen Mathematiker-Vereinigung, vol. 22, Nos. 5-6, pp. 135-140; June, 1913.

Wilczynski, E. J. Some General Aspects of Modern Geometry. Read Dec. 31, 1912. Bulletin of the American Mathematical Society, vol. 19, No. 7, pp. 331-342; April, 1913.

Ricerche geometriche intorno al Problema dei tre Corpi. Read (Chicago) Dec. 31, 1909, and (Chicago) Dec. 29, 1911. Annali di Matematica, vol. 21, pp. 1-31; Oct., 1913.

- On a Certain Class of Self-Projective Surfaces. Read Sept. 11, 1912. Transactions of the American Mathematical Society, vol. 14, No. 4, pp. 421-443; Oct., 1913.

Wiley, F. B. See Bliss, G. A.

Williams, K. P. The Linear Difference Equation of the First Order. Read (Chicago) Dec. 27, 1913. Annals of Mathematics, vol. 15, No. 3, pp. 129-135; March, 1914.

Winger, R. M. Self-Projective Rational Curves of the Fourth and Fifth Orders. Read Jan. 2, 1913. American Journal of Mathematics, vol. 36, No. 1, pp. 53-78; Jan., 1914. 